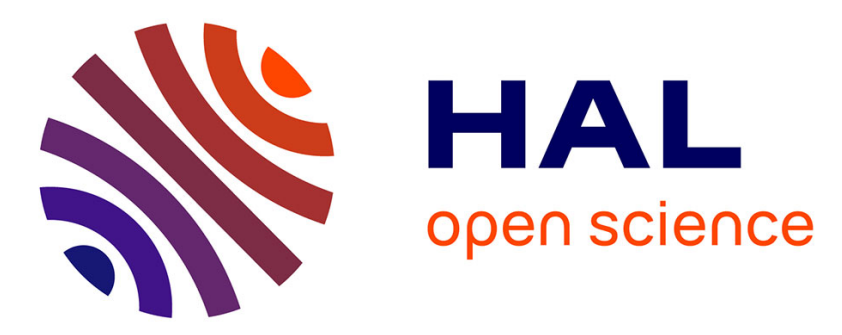

\title{
Biological Evaluation of the NIR-Emissive Ruby Analogue [Cr(ddpd)2][BF4]3 as a Photodynamic Therapy Photosensitizer
}

\author{
Uttara Basu, Sven Otto, Katja Heinze, Gilles Gasser
}

\section{To cite this version:}

Uttara Basu, Sven Otto, Katja Heinze, Gilles Gasser. Biological Evaluation of the NIR-Emissive Ruby Analogue [Cr(ddpd)2][BF4]3 as a Photodynamic Therapy Photosensitizer. European Journal of Inorganic Chemistry, 2019, 2019 (1), pp.37-41. 10.1002/ejic.201801023 hal-02115246

\author{
HAL Id: hal-02115246 \\ https://hal.science/hal-02115246
}

Submitted on 30 Apr 2019

HAL is a multi-disciplinary open access archive for the deposit and dissemination of scientific research documents, whether they are published or not. The documents may come from teaching and research institutions in France or abroad, or from public or private research centers.
L'archive ouverte pluridisciplinaire HAL, est destinée au dépôt et à la diffusion de documents scientifiques de niveau recherche, publiés ou non, émanant des établissements d'enseignement et de recherche français ou étrangers, des laboratoires publics ou privés. 


\title{
Biological Evaluation of the NIR-Emissive Ruby Analogue $\left[\mathrm{Cr}(\mathrm{ddpd})_{2}\right]\left[\mathrm{BF}_{4}\right]_{3}$ as a Photodynamic Therapy Photosensitizer
}

\author{
Uttara Basu,${ }^{[\mathrm{a}]}$ Sven Otto, ${ }^{[\mathrm{b}, \mathrm{c}]}$ Katja Heinze, ${ }^{[\mathrm{b}], *}$ and Gilles Gasser ${ }^{[\mathrm{a}], *}$
}

[a] Chimie ParisTech PSL University

Laboratory for Inorganic Chemical Biology

F-75005 Paris (France)

Email: gilles.gasser@chimieparistech.psl.eu

www.gassergroup.com

[b] Institute of Inorganic Chemistry and Analytical Chemistry

Johannes Gutenberg University of Mainz

Duesberweg 10-14 Mainz

D-55128 Mainz (Germany)

Email: katja.heinze@uni-mainze.de

https://www.ak-heinze.chemie.uni-mainz.de/

[c] Graduate School Materials Science in Mainz

Staudingerweg 9, D-55128 Mainz (Germany)

Abstract: Photodynamic therapy relies on the bioavailability of photosensitizers with suitable photophysical, chemical and biochemical properties. Although the photophysical properties, stability and high water solubility of the chromium(III) complex $\left[\mathrm{Cr}(\mathrm{ddpd})_{2}\right]\left[\mathrm{BF}_{4}\right]_{3}\left(\mathrm{ddpd}=N, N^{\prime}\right.$-dimethyl- $N, N^{\prime}$-dipyridin-2-ylpyridine-2,6-diamine) are very favorable, its photocytotoxicity against cancerous and non-cancerous cell lines has not yet been elucidated. We now report the cytotoxicity and photocytotoxicity of the complex $\left[\mathrm{Cr}(\mathrm{ddpd})_{2}\right]\left[\mathrm{BF}_{4}\right]_{3}$ against human cervical cancer cells, human primary glioblastoma cells, human glioblastoma astrocytoma cells and non-cancerous retinal pigment epithelium cells.

\section{Introduction}

Photodynamic therapy (PDT) is an approved medical technique that requires the combination of three individually nontoxic components to induce cellular and tissue effects, namely a photosensitizer (PS), oxygen and light. ${ }^{[1,2]}$ Typically, the PS is a photosensitive molecule that localizes to a target cell and/or tissue. Following the absorption of light, a typically employed PS such as Photofrin ${ }^{\circledR[3]}$ is transformed from its singlet ground state into a relatively long lived excited triplet state via a short lived excited singlet state followed by intersystem crossing. During its lifetime, the excited triplet state can undergo different reactions, namely direct reaction with a substrate, such as cell membrane components or other biologically important molecules to form radicals (photoredox reaction) or, alternatively, triplet oxygen can quench the excited triplet state forming singlet oxygen (energy transfer). Both these reactions occur close to the light absorbing PS. Consequently, the biological response to the PS evolves only in those areas of tissue that have been exposed to light. This mechanism accounts for the fact that side effects of PDT are generally much less severe than those of "conventional" chemotherapy.

Despite all advantages of PDT, the currently employed PDT PSs are not ideal in every respect. Current challenges comprise tedious synthetic procedures of the photosensitizer, employment of critical elements such as noble metals or rare earth elements, dye aggregation due to $\pi$ stacking, poor drug clearance that leads to prolonged photosensitivity in patients, poor drug solubility in aqueous solution or poor targeting ability. ${ }^{[4,5]}$ Metal complexes with their broad structural and chemical diversity are suitable drug alternatives, as demonstrated by some of us and others. ${ }^{[6-13]}$ While most of the typically employed dyes are complexes of the second and third row transition metal ions or lanthanide ions, or elaborated organic molecules, it is challenging to achieve long-lived phosphorescent excited states with first-row transition metal complexes. Moreover, many emitters efficiently decay to the ground state by a multitude of nonradiative pathways, such as low-energy dark excited states, energy transfer to high energy oscillators, excimer formation or direct surface crossing to the ground state. ${ }^{[14-16]}$ Such effects reduce the excited state lifetime inhibiting efficient bimolecular reactions with (biological) substrates. Beyond PDT, emissive dyes have found numerous applications in organic light emitting diodes, telecommunication, night vision readable displays, oxygen sensing, singlet oxygen formation, and in vivo imaging among others. ${ }^{[17-26]}$

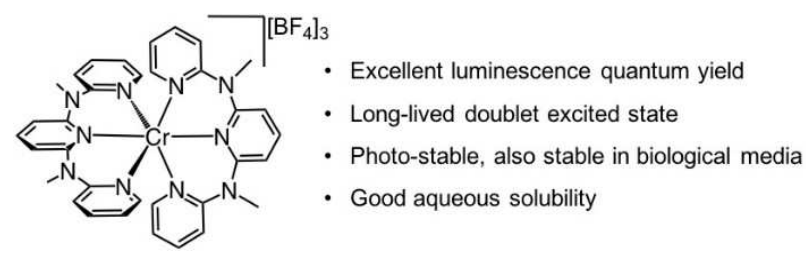


The excited state lifetimes of first row transition metal complexes are typically extremely short ${ }^{[14]}$ and only recently a few ground-breaking complexes have been identified apart from copper(I) complexes. ${ }^{[27-31]}$ A key to increase the excited state lifetime of $3 \mathrm{~d}$ metal complexes is to increase the ligand field splitting. Octahedral chromium(III) ions are suitable candidates as phosphorescent emitters with long excited state lifetimes. However, typical phosphorescence quantum yields for such $\mathrm{Cr}$ complexes are rather low $(<0.15 \%) .{ }^{[32]}$ Yet, photoredox catalysis using $\left[\mathrm{Cr}(\text { phen })_{3}\right]^{3+}$ derivatives proved successful confirming a suitable excited state lifetime. ${ }^{[33-35]}$ Widening the N-Cr-N bite angle close to $90^{\circ}$ and concomitant increasing of the ligand field splitting led to the complex $\left[\mathrm{Cr}(\mathrm{ddpd})_{2}\right]^{3+}$ with exceptionally favorable photophysical properties (ddpd $=N, N^{\prime}$-dimethyl- $N, N^{\prime}$-dipyridin-2-ylpyridine-2,6-diamine ${ }^{[36]}$; Scheme 1). ${ }^{[31,37]}$ The lifetime of the excited doublet state $\left({ }^{2} \mathrm{E}\right)$ of $\left[\mathrm{Cr}(\mathrm{ddpd})_{2}\right]^{3+}$ amounts to $898 \mu \mathrm{s}$ in water and the corresponding quantum yield to 11 $\%$ in the absence of $\mathrm{O}_{2}{ }^{\left[{ }^{[1]}\right.}$ These photophysical properties led to the notion of $\left[\mathrm{Cr}(\mathrm{ddpd})_{2}\right]^{3+}$ complexes as "molecular ruby". ${ }^{[31,37,38]}$ Deuteration of the solvent and the ligand even increases the quantum yield to $30 \%$ and the lifetime to more than 2 ms. $^{[38]}$

Oxygen quenches this emission with a bimolecular rate constant $k_{\mathrm{q}}=1.77 \times 10^{7} \mathrm{M}^{-1} \mathrm{~s}^{-1}$ and a Stern-Volmer constant $K_{\mathrm{Sv}}$ $=1.59 \times 10^{4} \mathrm{M}^{-1}$. ${ }^{[1]}$ In fact, singlet oxygen $\left({ }^{1} \mathrm{O}_{2}\right)$ forms due to energy transfer from the excited ${ }^{2} \mathrm{E}$ state of the chromium(III) complex to ${ }^{3} \mathrm{O}_{2}$ with $61 \%$ quantum yield in DMF. ${ }^{[39]}$ This feature of the chromium(III) complex has already been exploited in photocatalytic reactions of $\left[\mathrm{Cr}(\mathrm{ddpd})_{2}\right]^{3+}$ and oxygen. ${ }^{[39]}$ On the other hand, photoredox chemistry of this complex is not observed and its excited state reactivity is solely based on energy transfer reactions. The complex $\left[\mathrm{Cr}(\mathrm{ddpd})_{2}\right]\left[\mathrm{BF}_{4}\right]_{3}$ is highly water soluble. ${ }^{[31]}$ Furthermore, the cation $\left[\mathrm{Cr}(\mathrm{ddpd})_{2}\right]^{3+}$ is substitutionally stable both at neutral and at high $\mathrm{pH}$ in the dark in contrast to e.g. $\left[\mathrm{Cr}(\mathrm{tpy})_{2}\right]^{3+}{ }^{[31,40]}$ Even under irradiation with $430 \mathrm{~nm}$ LEDs at $\mathrm{pH} 7$ and at $\mathrm{pH} 11.4$ no photodecomposition is observed for at least $5 \mathrm{~h}$, in contrast to other typical chromium(III) complexes such as $\left[\mathrm{Cr}(\mathrm{bpy})_{3}\right]^{3+}$, which undergo photosubstitution. ${ }^{[31,37]}$ The very favorable chemical and photophysical properties of $\left[\mathrm{Cr}(\mathrm{ddpd})_{2}\right]\left[\mathrm{BF}_{4}\right]_{3}$, namely high excited state lifetime, high singlet oxygen quantum yield under irradiation, high water solubility and high photostability, prompted us to explore the potential of this chromium(III) complex as PS in PDT applications against cancer cell lines.

Chromium, specifically in its trivalent state is reported as an essential trace element and small amounts are beneficial for improving blood-sugar levels for patients suffering from prediabetes or type 1 and type 2 diabetes. It is also used for depression, Turner's syndrome, polycystic ovary syndrome, lowering "bad" cholesterol, raising "good" cholesterol in people taking heart medications called beta blockers, metabolic syndrome and heart attack. Some people even try chromium(III) for body conditioning including weight loss, increasing muscle, and decreasing body fat. Chromium is also suggested to improve athletic performance, to increase energy, and to prevent age-related mental decline. The absorption of chromium is less than $2 \%$ in the intestines and chromium picolinate is used as a supplement. ${ }^{[11-43]}$ Chromium(III) complexes show effects against different bacterial strains like S. aureus and E. coli ${ }^{[44]}$ and further studies report the potential of such complexes against human dermal fibroblasts. ${ }^{[45]}$ As a serious note of caution, Lay and coworkers have demonstrated that chromium(III) complexes with labile ligands can be transformed to carcinogenic chromium(VI) species in adipocytes. ${ }^{[46]}$ We note also that organometallic chromium(0) complexes have been used for medicinal applications ${ }^{[47-49]}$ To the best of our knowledge, photocytotoxicity studies of chromium(III) complexes have not yet been reported.

The present study reports the stability of $\left[\mathrm{Cr}(\mathrm{ddpd})_{2}\right]\left[\mathrm{BF}_{4}\right]_{3}$ in biological media, its cytotoxicity and its photocytotoxicity for use as a potential PDT PS against cancer cell lines.

\section{Results and Discussion}

Human Plasma Stability. Based on the favorable stability of $\left[\mathrm{Cr}(\mathrm{ddpd})_{2}\right]^{3+}$ cations in organic and aqueous media, ${ }^{[31]}$ we extended these stability tests to a biological medium, specifically human plasma. The stability of the complex in human plasma was checked at different time intervals using an adapted method performed previously for other complexes by some of us. ${ }^{[11]}$ We incubated the complex in human plasma for $4 \mathrm{~h}, 24 \mathrm{~h}$, and $48 \mathrm{~h}$ at $37^{\circ} \mathrm{C}$ and assessed its stability using high performance liquid chromatography (HPLC). Caffeine was used an internal control since it is known to be stable in these conditions. The data displayed in Figure 1 confirm the high stability under these experimental conditions indicating its suitability as a PDT PS. 


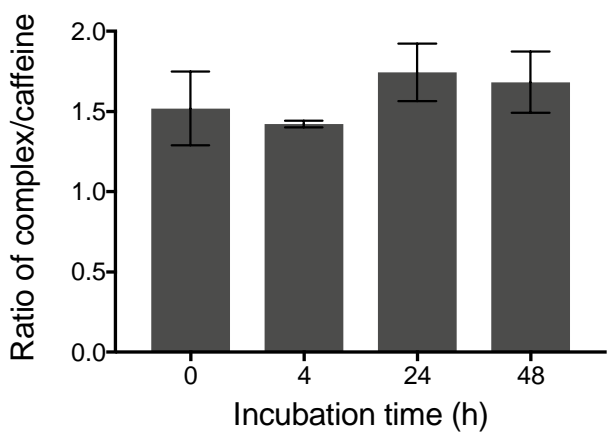

Figure 1. Ratio of $\left[\mathrm{Cr}(\mathrm{ddpd})_{2}\right]^{3+}$ to caffeine (internal standard) at different time intervals $(0 \mathrm{~h}, 4 \mathrm{~h}, 24 \mathrm{~h}, 48 \mathrm{~h})$ in human plasma.

Cytotoxicity and Photocytotoxicity. Cytotoxicity and photocytotoxicity of $\left[\mathrm{Cr}(\mathrm{ddpd})_{2}\right]\left[\mathrm{BF}_{4}\right]_{3}$ were evaluated using human cervical cancer cells (HeLa), human primary glioblastoma cells (U87), human glioblastoma astrocytoma cells (U373 MG) and non-cancerous retinal pigment epithelium (RPE-1) cells. After $4 \mathrm{~h}$ incubation with the complex in the respective culture medium of the cell lines at different concentration and exchange of the comlex-containing medium against Cr-free medium the cells were irradiated with $450 \mathrm{~nm}$ LEDs $\left(10 \mathrm{mins}, 7.6 \mathrm{~J} \mathrm{~cm}^{-2}\right)$. Control experiments were conducted in the dark. Without irradiation, $\left[\mathrm{Cr}(\mathrm{ddpd})_{2}\right]^{3+}$ is only weakly cell-toxic with $\mathrm{IC}_{50}$ values of around $200 \mu \mathrm{M}$ for all cancer cells. Upon light irradiation, the cytotoxicity of the complex increased only fivefold (i.e. photocytotoxicity index PI = 5) (Figure 2 and Table 1). Considering the luminescence quantum yield, the excited state lifetime and the ${ }^{1} \mathrm{O}_{2}$ quantum yield of $\left[\mathrm{Cr}(\mathrm{ddpd})_{2}\right]^{3+}$ a markedly higher $\mathrm{PI}$ was anticipated. ${ }^{[31,39]}$ Possibly, cellular internalization of $\left[\mathrm{Cr}(\mathrm{ddpd})_{2}\right]^{3+}$ is insufficient and consequently, the incubation time was extended to $24 \mathrm{~h}$. Yet, this measure did not increase the photocytotoxicity index (Table 1). To test the hypothesis that the water-soluble complex displays only poor cellular internalization, we checked its luminescence in cells using confocal microscopy. Despite several attempts at high complex concentration up to $250 \mu \mathrm{M}$, luminescence of the cells could not be detected by the confocal microscope.
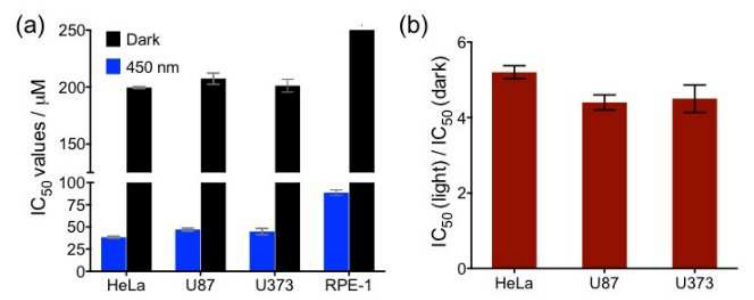

Figure 2. (a) Photocytotoxicity of $\left.\left[\mathrm{Cr}(\mathrm{ddpd})_{2}\right)\right]\left[\mathrm{BF}_{4}\right]_{3}$ after $4 \mathrm{~h}$ incubation in different cell lines with irradiation at $450 \mathrm{~nm}, 10 \mathrm{mins}, 7.6 \mathrm{~J} \mathrm{~cm}{ }^{-2}(\mathrm{blue})$ or in the dark (black). (b) Photocytotoxicity index of the complex in HeLa, U87 and U353MG cells.

\begin{tabular}{lllll}
\hline $\begin{array}{l}\left.\text { Table 1. } \mathrm{IC}_{50} \text { values of }\left[\mathrm{Cr}(\mathrm{ddpd})_{2}\right)\right]\left[\mathrm{BF}_{4}\right]_{3} \text { in different cell lines with and } \\
\text { without irradiation. }\end{array}$ \\
\hline Cell line & $\begin{array}{l}\mathrm{IC}_{50}(450 \mathrm{~nm}) \\
\mu \mathrm{M}\end{array}$ & [a] $/$ & $\mathrm{IC}_{50}($ dark $) / \mu \mathrm{M}$ & $\begin{array}{l}\text { Photo- } \\
\text { cytotoxicity } \\
\text { index }(\mathrm{PI})\end{array}$ \\
\hline HeLa & $\begin{array}{l}38.4 \pm 1.2 \\
1.9)\end{array}$ & $(39.8 \pm$ & $\begin{array}{l}199.5 \pm 1.2 \\
(202.8 \pm 1.1)\end{array}$ & 5.2 \\
\hline U87 & $\begin{array}{l}47.0 \pm 1.7 \\
2.2)\end{array}$ & $(45.1 \pm$ & $\begin{array}{l}207.4 \pm 4.7 \\
(215.9 \pm 3.1)\end{array}$ & 4.4 \\
\hline U373MG & $\begin{array}{l}44.8 \pm 3.6 \\
2.5)\end{array}$ & $(46.9 \pm$ & $\begin{array}{l}201.2 \pm 5.5 \\
(202.1 \pm 3.9)\end{array}$ & 4.5 \\
\hline RPE-1 & $89.2 \pm 3.2(82.2 \pm 4.2)$ & $>250(>250)$ & $\mathrm{ND}$ \\
\hline
\end{tabular}

[a] Dose of irradiation was $7.6 \mathrm{~J} \mathrm{~cm}^{-2,} 10$ mins. Values in parenthesis indicate $\mathrm{IC}_{50}$ values obtained after $24 \mathrm{~h}$ incubation with $\left[\mathrm{Cr}(\mathrm{ddpd})_{2}\right]\left[\mathrm{BF}_{4}\right]_{3}$. ND indicates not determined

Possibly, the trication

$\left[\mathrm{Cr}(\mathrm{ddpd})_{2}\right]^{3+}$ is unable to cross cell membranes. This could be due to its high charge and consequently poor lipophilicity. To support this assumption, we investigated the ion paring properties of $\left[\mathrm{Cr}(\mathrm{ddpd})_{2}\right]\left[\mathrm{BF}_{4}\right]_{3}$ and the lipophilicity. 
Lipophilicity Measurements (Log P). To obtain an insight into the poor cellular uptake behavior of the $\left[\operatorname{Cr}(\mathrm{ddpd})_{2}\right]^{3+}$ complex, we evaluated its lipophilicity from its partition coefficient in a PBS-octanol system. Ferrocene was used as a reference. Under identical experimental conditions, the chromium(III) complex had a lipophilicity value of -1.1 while that for the ferrocene was 1.4. This clearly indicates that the compound is very hydrophilic and this probably leads to a poor cellular uptake. This can certainly account for the very modest cytotoxicity values observed.

Conductivity. In order to obtain an impression of the effective charge of the chromium(III) $\operatorname{salt}\left[\mathrm{Cr}(\mathrm{ddpd})_{2}\right]\left[\mathrm{BF}_{4}\right]_{3}$ in solution, its conductivity in $\mathrm{CH}_{3} \mathrm{CN}$ solution was determined. Its experimentally determined equivalent conductivity amounts to $\Lambda_{0}=263 \mathrm{~S} \mathrm{~cm}^{-1} \mathrm{M}^{-1}$. This conductivity is larger than for the $1: 1$ electrolyte [ $\left.{ }^{\mathrm{n}} \mathrm{Bu}_{4} \mathrm{~N}\right]\left[\mathrm{BF}_{4}\right]$ with $\Lambda_{0}=177 \mathrm{~S} \mathrm{~cm}^{-1}$ $\mathrm{M}^{-1}$ (Figure 3) but lower than that of typical $1: 3$ electrolytes with $\Lambda_{0}=340-420 \mathrm{~S} \mathrm{~cm}^{-1} \mathrm{M}^{-1}$. ${ }^{[50]}$ Hence under these conditions, $\left[\mathrm{Cr}(\mathrm{ddpd})_{2}\right]\left[\mathrm{BF}_{4}\right]_{3}$ behaves as a 1:2 electrolyte and the average charge of the ion pairs $\left\{\left[\mathrm{Cr}(\mathrm{ddpd})_{2}\right]\left[\mathrm{BF}_{4}\right]_{n}\right\}^{3-n}$ amounts to $2+$. Similar charge values are expected in water or plasma. Obviously, reduction of the high positive charge of $3+$ of the chromium(II) complex to $2+$ due to counter ion association is insufficient to allow this complex ion pair to cross cell membranes efficiently. Hence, other strategies such as increasing the lipophilicity by suitable substituents, conjugation with cell penetrating peptides ${ }^{[51]}$ or reduction of the overall complex charge have to be devised to allow this complex entering cells.

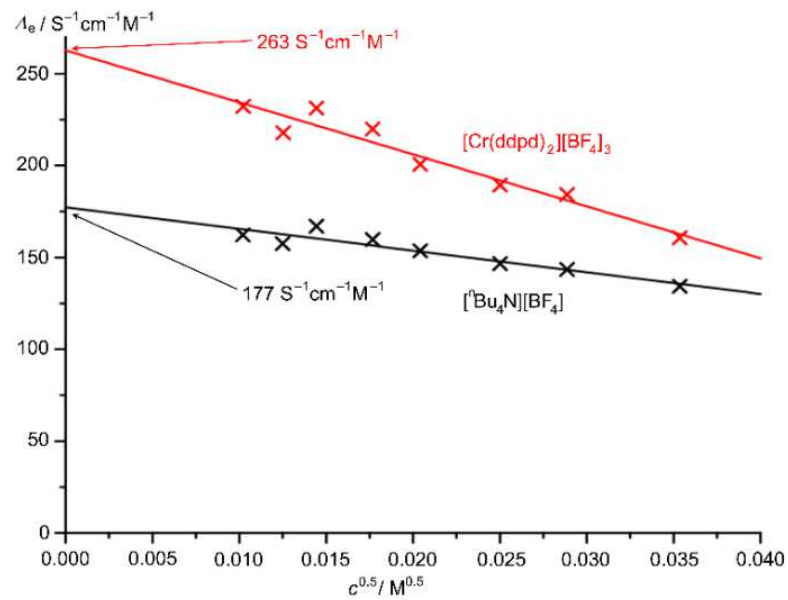

Figure 3. Conductivity measurements of $\left[\mathrm{Cr}(\mathrm{ddpd})_{2}\right]\left[\mathrm{BF}_{4}\right]_{3}$ and the $1: 1$ electrolyte reference $\left[{ }^{\mathrm{n}} \mathrm{Bu}_{4} \mathrm{~N}\right]\left[\mathrm{BF}_{4}\right]$ in $\mathrm{CH}_{3} \mathrm{CN}$.

\section{Conclusions}

This study describes the (photo-)cytotoxic properties of the water soluble, stable, luminescent chromium(III) complex $\left[\mathrm{Cr}(\mathrm{ddpd})_{2}\right]\left[\mathrm{BF}_{4}\right]_{3}$. In the dark, $\left[\mathrm{Cr}(\mathrm{ddpd})_{2}\right]\left[\mathrm{BF}_{4}\right]_{3}$ is essentially non-toxic to various cell lines. Although $\left.\left[\mathrm{Cr}(\mathrm{ddpd})_{2}\right][\mathrm{BF}]_{4}\right]_{3}$ is able to form singlet oxygen from triplet oxygen under light irradiation, its phototoxic index is relatively poor. Consequently, $\left[\mathrm{Cr}(\mathrm{ddpd})_{2}\right]\left[\mathrm{BF}_{4}\right]_{3}$ is unsuitable as photosensitizer for photodynamic therapy. The poor performance has been ascribed to the insufficient internalization of the complex cation into the cell. Although, ion paring reduces the overall charge somewhat, the lipophilicity and cell permeability are obviously too low for efficient cellular accumulation. In the future, we aim to modify the chromium(III) complex by decreasing the overall positive charge and/or decorating with hydrophobic groups on the ligand periphery to improve the cellular uptake and enable its use as a PDT PS.

\section{Experimental Section}

Materials. Dulbecco's Modified Eagles Medium (DMEM, catalogue number 11500416), Dulbecco's Modified Eagles Medium supplemented with nutrient mixture F-12 (DMEM/ F-12, catalogue number 11580546), fetal bovine serum (FBS, catalogue number 11573397), Gibco ${ }^{\text {TM }}$ Penicillin-Streptomycin-Glutamine (penstrep, catalogue number 12090216), Gibco'TM MEM Non-Essential Amino Acids Solution (catalogue number 11140050, Dulbecco's PhosphateBuffered Saline (DPBS, catalogue number 12559069), Trypsin-EDTA (catalogue number 11560626) and resazurin (catalogue number 10751244 were purchased from Fisher Scientific. $\left[\mathrm{Cr}(\mathrm{ddpd})_{2}\right]\left[\mathrm{BF}_{4}\right]_{3}$ was synthesized as previously described. ${ }^{[31]}$

Cell culture. HeLa cells were cultured in DMEM, RPE-1 cells were cultured in DMEM/ F-12, U87 and U373MG cells were cultured in MEM media having 1\% NEAA and reconstituted with 10\% FBS and 1\% penstrep. Cells were grown in a humidified cell culture incubator at $37{ }^{\circ} \mathrm{C}$ and with $5 \% \mathrm{CO}_{2}$ and passaged three times before using for the experiments. 
Stability Studies in human plasma. Stability study of the complex in human plasma was performed by a slightly modified method. ${ }^{[11]}$ Caffeine was obtained from TCl chemicals and used as the internal standard. The human plasma was procured from Fischer Scientific (Gibco). For each experiment, fresh stock solutions of the complex (1.0 mM), and caffeine $(1.0 \mathrm{mM})$ were prepared in DMSO and protected from light. Final concentration of the complex and caffeine in plasma was $50 \mu \mathrm{M}$ and $20 \mu \mathrm{M}$ respectively. The resulting solutions were incubated for $0 \mathrm{~h}, 4 \mathrm{~h}, 24 \mathrm{~h}$ and $48 \mathrm{~h}$ at $37^{\circ} \mathrm{C}$ with continuous shaking $(500 \mathrm{rpm})$ while still being protected from light. The plasma solutions were quenched with $2 \mathrm{~mL}$ methanol and the mixtures were centrifuged at $3000 \mathrm{rpm}$ for $1 \mathrm{~h}$ at $4^{\circ} \mathrm{C}$. The organic solvent was evaporated and the residue was dried overnight in vacuum. It was re-suspended in $100 \mu \mathrm{L}$ of $1: 1(\mathrm{v} / \mathrm{v}) \mathrm{CH}_{3} \mathrm{CN} / \mathrm{H}_{2} \mathrm{O}$ solution, the suspension was filtered with $0.2 \mu \mathrm{m}$ filters and analysed using HPLC (Agilent 1260).

Photocytotoxicity Studies. Cells were seeded at a density of 4000 cells/well in $100 \mu \mathrm{L}$ media and grown overnight in a humidified cell culture incubator at $37{ }^{\circ} \mathrm{C}$ and with $5 \% \mathrm{CO}_{2}$. All experiments were performed in triplicates. The media was removed and replenished with varied concentrations of the $\mathrm{Cr}$ (III) complex diluted in appropriate volume of the culture media in a total volume of $200 \mu \mathrm{L}$. They were incubated for $4 \mathrm{~h}$ (or $24 \mathrm{~h}$ ) and replaced with $200 \mu \mathrm{L}$ of fresh culture media. Three of the plates were irradiated at $450 \mathrm{~nm}$ (dose: $7.6 \mathrm{~J} \mathrm{~cm}^{-2}$ ). Irradiation was performed in the 96-well culture plates using a LUMOS-BIO photoreactor (Atlas Photonics, Switzerland). Each well was individually illuminated with a $50 \mathrm{~mW}$ LED at constant current and the temperature of the plates was maintained constant at $37^{\circ} \mathrm{C}$ with a cooling system. Total time of irradiation was 10 mins for HeLa, U87 and U373 cells, and $5 \times 2$ mins for RPE-1 with 15 min intervals in between each irradiation. The cells were then allowed to grow in the incubator for another $44 \mathrm{~h}$ (or $24 \mathrm{~h}$ ). In the three other plates for the dark cytotoxicity control, the media was removed after $4 \mathrm{~h}$ (or $24 \mathrm{~h}$ ), replaced with 200 $\mu \mathrm{L}$ of fresh culture media and incubated for another $44 \mathrm{~h}$ (or $24 \mathrm{~h}$ ). After $48 \mathrm{~h}$ of the initial treatment, the media was exchanged for resazurin solution $\left(0.2 \mathrm{mg} \mathrm{mL}^{-1}\right)$ made in the respective culture media and sterile filtered. After $4 \mathrm{~h}$ incubation, the fluorescence of the product resorufin was measured at $590 \mathrm{~nm}$ with excitation at $540 \mathrm{~nm}$ using a Spectramax M5 UV-visible spectrophotometer. The data was analysed and plot using Graph Pad Prism 8.

Lipophilicity Measurements. The lipophilicity of the $\mathrm{Cr}$ (III) complex was measured with respect to ferrocene in a PBSoctanol system from the partition coefficient value $(\log P)$. The analytes were dissolved in DMSO to make a stock solution and then added to a 1:1 PBS/octanol pre-saturated mixture such that the final concentration was $200 \mu \mathrm{M}$ and $220 \mu \mathrm{M}$ for ferrocene and the complex respectively. The mixtures were vortexed for $1 \mathrm{~h}$ and allowed to equilibrate at room temperature for another $2 \mathrm{~h}$. The concentration in the two phases was determined by measuring the absorbance values at $445 \mathrm{~nm}$ and $435 \mathrm{~nm}$ for ferrocene and $\left[\mathrm{Cr}(\mathrm{ddpd})_{2}\right]^{3}$ respectively using previously determined calibration curves. Lipophilicity values were calculated using the formula $\log \left\{[C]_{o c t} /[C]_{a q}\right\}$ where $C_{o c t}$ and $C_{a q}$ denote the analyte concentration in the octanol or the aqueous phase respectively.

Confocal Microscopy. HeLa cells were grown in BioLite $35 \mathrm{~mm}$ confocal imaging glass dishes at a seeding density of 5000 cells/ dish in DMEM supplemented with $10 \% \mathrm{FBS}$ at $37{ }^{\circ} \mathrm{C}$ in $5 \% \mathrm{CO}_{2}$. They were treated with $\left[\mathrm{Cr}(\mathrm{ddpd})_{2}\right]\left(\mathrm{BF}_{4}\right)_{3}$ incubated for $4 \mathrm{~h}$ or $24 \mathrm{~h}$. The media was removed and cells were washed thrice with PBS. They were further incubated with 2 drops per $\mathrm{mL}$ of media of NucBlue ${ }^{\circledR}$ Live ReadyProbes ${ }^{\circledR}$ for 30 mins at room temperature. Finally, cells were washed with thrice PBS and phenol free media ( $2 \mathrm{~mL} /$ dish) was added. Live cell images were recorded using a Zeiss confocal microscope using excitation at $454 \mathrm{~nm}$ and emission filter was set at $>600 \mathrm{~nm}$.

Conductivity measurements. Conductivities were measured with a Greisinger conductivity cell, model 6MH 3431 LFE210 with platinum electrodes in the concentration range $10^{-6}-10^{-4} \mathrm{M}$ in dry acetonitrile under inert atmosphere. The equivalent conductivity $\Lambda_{\mathrm{e}}$ was plotted as a function of $c^{0.5}$. To determine $\Lambda_{0}, \Lambda_{\mathrm{e}}$ was extrapolated to infinite dilution.

\section{Acknowledgements}

This work was financially supported by an ERC Consolidator Grant PhotoMedMet to G.G. (GA 681679), by the Deutsche Forschungsgemeinschaft (HE 2778/10-1 grant to K.H. and GSC 266, Materials Science in Mainz, scholarship for S.O.) and has received support under the program "Investissements d' Avenir" launched by the French Government and implemented by the ANR with the reference ANR-10-IDEX-0001-02 PSL (G.G.).

Keywords: Chromium • cytotoxicity $\cdot$ photocytotoxicity $\cdot$ photodynamic therapy $\bullet$ singlet oxygen 


\section{References}

[1] D. E. J. G. J. Dolmans, D. Fukumura, R. K. Jain, Nat. Rev. Cancer 2003, 3, 380-387.

[2] X. Wen, Y. Li, M. R. Hamblin, Photodiagn. Photodyn. 2017, 19, 140-152.

[3] A. B. Ormond, H. S. Freeman, Materials 2013, 6, 817-840.

[4] X. Peng, F. Song, E. Lu, Y. Wang, W. Zhou, J. Fan, Y. Gao, J. Am. Chem. Soc. 2005, 127, 4170-4171.

[5] J. O. Escobedo, O. Rusin, S. Lim, R. M. Strongin, Curr. Opin. Chem. Biol. 2010, 14, 64-70.

[6] N. A. Smith, P. J. Sadler, Phil. Trans. Soc. A 2013, 371, 20120519.

[7] N. J. Farrer, L. Salassa, P. J. Sadler, Dalton Trans. 2009, 10690-10701.

[8] U. Basu, I. Khan, A. Hussain, P. Kondaiah, A. R. Chakravarty, Angew. Chem. 2012, 124, 2712-2715; Angew. Chem. Int. Ed. 2012, 51, 2658-2661. b) P. Prasad, I. Khan, P. Kondaiah, A. R. Chakravarty, Chem. Eur. J. 2013, 19, 17445-17455; c) K. Mitra, S. Gautam, P. Kondaiah, A. R. Chakravarty, Angew. Chem. 2015, 54, 13989-13993; Angew. Chem. Int. Ed. 2015, 54, 13989-1399.

[9] M. A. Sgambellone, A. David, R. N. Garner, K. R. Dunbar, C. Turro, J. Am. Chem. Soc. 2013, 135, 11274-11282.

[10] H. Huang, B. Yu, P. Zhang, J. Huang, Y. Chen, G. Gasser, L. Ji, H. Chao, Angew. Chem. 2015, 127, 14255-14258; Angew. Chem. Int. Ed., 2015, 54, 14049-14052.

[11] C. Mari, V. Pierroz, R. Rubbiani, M. Patra, J. Hess, B. Spingler, J. Schur, L. Oehninger, I. Ott, L. Salassa, S. Ferrari, G. Gasser, Chem. Eur. J., 2014, 44, 14421-14436.

[12] P. Ung, M. Clerc, H. Huang, H. Chao, M. Seitz, B. Boyd, B. Graham, G. Gasser, Inorg. Chem. 2017, 56, 7960-7974.

[13] J. Hess, H. Huang, A. Kaiser, V. Pierroz, O. Blacque, H. Chao, G. Gasser, Chem. Eur. J., 2017, $23,9888-9896$.

[14] P. S. Wagenknecht, P. C. Ford, Coord. Chem. Rev. 2011, 255, 591-616.

[15] C. Kreitner, K. Heinze, Dalton. Trans. 2016, 45, 13631-13647.

[16] E. Kreidt, C. Kruck, M. Seitz, Handbook on the Physics and Chemistry of Rare Earths (Eds. J. C.-G. Bünzli, V. K. Pecharsky) 2018, vol. 53, Elsevier Amsterdam, pp. 35-79.

[17] C. L. Amiot, S. Xu, S. Liang, L. Pan, J. X. Zhao Sensors 2008, 8, 3082-3105.

[18] Zampetti, A. Minotto, B. M. Squeo, V. G. Gregoriou, S. Allard, U. Scherf, C. L. Chochos, F. Cacialli, Scientific Reports $2017,7,1611$.

[19] M. S. White, M. Kaltenbrunner, E. D. Głowacki, K. Gutnichenko, G. Kettlgruber, I. Graz, S. Aazou, C. Ulbricht, D. A. M. Egbe, M.C. Miron, Z. Major, M. C. Scharber, T. Sekitani, T. Someya, S. Bauer, N. S. Sariciftci Nat. Photonics 2013 7, 811-816.

[20] T. Sekitani, T. Someya, Adv. Mater. 2010, 22, 2228-2246.

[21] D. Y. Kim, D. W. Song, N. Chopra, P. De Somer, F. So, Adv. Mater. 2010, 22, 2260-2263.

[22] G. Zhang, H. Zhang, Y. Gao, R. Tao, L. Xin, J. Yi, F.Li, W. Liu, J. Qiao Organometallics 2014, 33, 61-68.

[23] Q. Liu, X. Zou, Y. Shi, B. Shen, C. Cao, S. Cheng, W. Feng, F. Li Nanoscale 2018, 10, 12573-12581.

[24] D. Château, Q. Bellier, F. Chaput, P. Feneyrou, G. Berginc, O. Maury, C. Andraud, S. Parola J. Mater. Chem. C 2014, 2, 5105-5110.

[25] Y. K. Lee, E. E. Ulbrich, G. Kim, H. Hah, C.Strollo, W. Fan, R. Gurjar, S. Koo, R. Kopelman, Anal. Chem. $2010,82,8446-8455$.

[26] N. P. Kamat, Z. Liao, L. E. Dmochowski, D. A. Hammer, Proc. Natl. Acad. Sci. USA 2011, 108, 13984-13989.

[27] P. Chábera, Y. Liu, O. Prakash, E. Thyrhaug, A. El Nahhas, A. Honarfar, S. Essén, L. A. Fredin, T. C. B. Harlang, K. S. Kjaer, K. Handrup, F. Ericsson, Y. Tatsuno, K. Morgan, J. Schnadt, L. Häggström, T. Ericsson, A. Sobkowiak, S. Lidin, P. Huang, S. Styring, J. Uhlig, J. Bendix, R. Lomoth, V. Sundström, P. Persson, K. Wärnmark, Nature 2017, 543, 695-699.

[28] L. A. Büldt, X. Guo, R. Vogel, A. Prescimone, O. S. Wenger, J. Am. Chem. Soc. 2017, 139, 985-992.

[29] L. A. Büldt, C. B. Larsen, O. S. Wenger, Chem. Eur. J. 2017, 23, 8577-8580.

[30] A. K. Pal, C. Li, G. S. Hanan, E. Zysman-Colman, Angew. Chem. 2018, 57, 8027-8031; Angew. Chem. Int. Ed. 2018, 57, 8027-8031.

[31] S. Otto, M. Grabolle, C. Förster, C. Kreitner, U. Resch-Genger, K. Heinze, Angew. Chem. 2015, 54, 11572-11576; Angew. Chem. Int. Ed. 2015, 54, 11572-11576.

[32] H. Xiang, J. Cheng, X. Ma, X. Zhou, J. Chruma, Chem. Soc. Rev. 2013, 42, 6128-6185.

[33] S. M. Stevenson, M. P. Shores, E. M. Ferreira, Angew. Chem. 2015, 127, 6606-6610; Angew. Chem. Int. Ed. 2015, 54, 6506-6510.

[34] R. F. Higgins, S. M. Fatur, S. G. Shepard, S. M. Stevenson, D. J. Boston, E. M. Ferreira, N. H. Damrauer, A. K. Rappé, M. P. Shores, J. Am. Chem. Soc. 2016, 138, 5451-5464.

[35] S. M. Stevenson, R. F. Higgins, M. P. Shores, E. M. Ferreira, Chem. Sci. 2017, 8, 654-660.

[36] a) A. Breivogel, C. Förster, K. Heinze, K. Inorg. Chem. 2010, 49, 7052-7056; b) C. Förster, M. Dorn, T. Reuter, S. Otto, G. Davarci, T. Reich, L. Carrella, E. Rentschler, K. Heinze, Inorganics 2018, 6, 86.

[37] S. Otto, M. Dorn, C. Förster, M. Bauer, M. Seitz, K. Heinze, Coord. Chem. Rev. 2018, 359, 102-111.

[38] C. Wang, S. Otto, M. Dorn, E. Kreidt, J. Lebon, L. Sršan, P. Di Martino-Fumo, M. Gerhards, U. Resch-Genger, M. Seitz, K. Heinze, Angew. Chem. 2018, 130, 1125-1130; Angew. Chem. Int. Ed. 2018, 57, 1112-1116.

[39] S. Otto, A. M. Nauth, E. Ermilov, N. Scholz, A. Friedrich, U. Resch-Genger, S. Lochbrunner, T. Opatz, K. Heinze, ChemPhotoChem 2017, 1, 344-349.

[40] E. C. Constable, C. E. Housecroft, M. Neuburger, J. Schönle, J. A. Zampese, Dalton Trans. 2014, 43, 7227-7235.

[41] D. A. Eastmond, J. T. Macgregor, R. S. Slesinski Crit. Rev. Toxicol. 2008; 38, 173-90.

[42] A. Levina, P. A. Lay Chem. Res. Toxicol. 2008, 21, 563-571.

[43] M. Figgitt, R. Newson, I. J. Leslie, J. Fisher, E. Ingham, C. P. Case, Mutation Res. 2010, 688, $53-61$.

[44] P. L. Páez, C. M. Bazán, M. E. Bongiovanni, J. Toneatto, I. Albesa, M. C. Becerra, G. A. Argüello, BioMed Res. Int. 2013, Article ID 906912

[45] H. Y. Shrivastava, T. Ravikumar, N. Shanmugasundaram, Mary Babu, B. U. Nair, Free Radic. Biol. Med. $2005,38,58-69$.

[46] L. E. Wu, A. Levina, H. H. Harris, Z. Cai, B. Lai, S. Vogt, D. E. James, P. A. Lay, Angew. Chem. 2015, 55, 1742-1745; Angew. Chem. Int. Ed. 2015, 55, 1742-1745.

[47] M. Patra, K. Ingram, V. Pierroz, S. Ferrari, B. Spingler, R. B. Gasser, J. Keiser, G. Gasser, Chem. Eur. J. $2013,19,2232-2235$.

[48] S. Clède, N. Cowan, F. Lambert, H. C. Bertrand, R. Rubbiani, M. Patra, J. Hess, C. Sandt, N. Trcera, G. Gasser, J. Keiser, C. Policar, ChemBioChem 2016, 17, 1004-1007.

[49] H. Bielig, J. Velder, A. Saiai, M. Menning, S. Meemboor, W. Kalka-Moll, M. Krönke, H.-G. Schmalz, T. A. Kufer, ChemMedChem 2010, 5, 2065-2071.

[50] W. J. Geary, Coord. Chem. Rev. 1971, 7, 81-122.

[51] D. Kalafatovic, E. Giralt, Molecules 2017, 22, 1929. 
